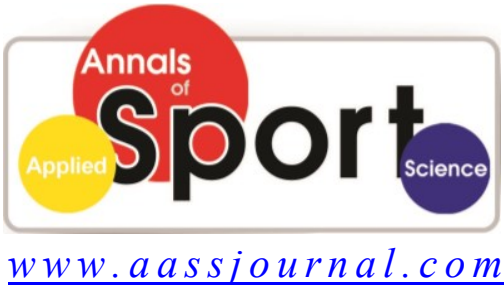

ISS N (Online): $2322-4479$

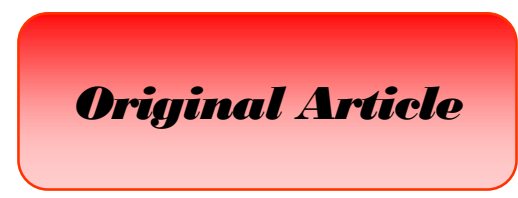

Received: $15 / 10 / 2013$

Accepted: 09/03/2014

\title{
Determination of Barriers to E-Commerce in Companies Producing Sports Equipment and Goods: the Perspective of Sport Managers in Iran
}

\section{${ }^{1}$ Seyed Gholamreza Razavi, ${ }^{2}$ Seyed Emad Hosseini* ${ }^{3}$ Seyed Mohammad Hossein Razavi}

1. Department of Sport Management, Shomal University, Amol, Iran.

2. Department of Sport Management, Shahid Beheshti University, Tehran, Iran.

3. Department of Sport Management, Mazandaran University, Babolsar, Iran.

\begin{abstract}
Today, e-commerce has become a top priority for organizations. By getting use of the Internet, organizations can significantly influence the attitudes of their customers and encourage them to benefit from the services provided by them. Consequently, organizations can affordably become a leader in the market, supply, delivery, and service. Furthermore, development of e-commerce in all existing fields is faced with major obstacles and challenges. Hence, the objective of the present paper was to identify the obstacles to e-commerce in companies producing sports equipment and goods from the perspective of sports managers in Iran. Statistical population included sports general directors of youth and sports offices, presidents of active federations, and executive managers of Ministry of Youth and Sports. Due to limited number of population members, it was completely considered as the sample $(n=57)$. The required data were collected in two parts; firstly, data on theatrical information and previous studies were collected through reviewing the library resources, the Internet, papers, and dissertations about the barriers to e-commerce and second, a questionnaire was used to collect information about the research questions. The results showed that 7 factors including readiness of customers, readiness of companies, administrative barriers, lack of adequate competition, technological barriers, legal barriers, and financial barriers with coefficients of 0.883 , $0.859,0.853,0.836,0.801,0.796$, and 0.692 , respectively, have the first to seventh ranking among the barriers to e-commerce in this sector.
\end{abstract}

Key Words: E-Commerce, Sports Equipment, Sports Goods, Customer Readiness, Barriers.

Corresponding Author:

Seyed Gholamreza Razavi

E-mail: razavi.shomal@yahoo.com 


\section{INTRODUCTION}

Many economists and experts believe that a revolution like the Industrial Revolution has entered the world into the information era and has greatly changed many economic, social, cultural, and sports aspects of human life.

Today, e-commerce has become a top priority for organizations. By getting use of the Internet, organizations can significantly influence the attitudes of their customers and encourage them to benefit from the service provided by them. Consequently, organizations can affordably become a leader in the market, supply, delivery, and service. However, one of the obstacles to the development and success of e-commerce is distrust which has been mentioned over and over as a barrier to the participation of consumers in online transactions, putting the future of e-commerce at risk. E-commerce is not just a choice for organizations but it is an inescapable principle for maintaining the competitive advantage which leads to increased quality, dynamism, and customer market accessibility and decreased price and market accessibility time. In such circumstances, business organizations should compete with more rivals and being a leading company in e-commerce cannot be simply realized (1).

Presence in global markets through resorting to the successful and efficient practices can be a symbol of economic empowerment of countries. Information and communication technology has made dramatic changes in the business world, such as evolution of business and its approach towards e-commerce. Although e-commerce is a young phenomenon, it has caused considerable effects on trade and business. Successful achievements in e-commerce using the computer networks can be used in identification of target markets, marketing, direct links between demand and supply agents of goods and services, reduction of time and acceleration of business procedures, exchange of required information and documents, banking operations, insurance services, certificates required for entry and exit of goods, shipping and delivery of goods, dissemination of information and breaking its monopoly, and providing more accurate information dissemination process. Being on the road of economic development has always been considered as one of the major concerns for developing countries. Increased production and income, which has always been the top economic program of countries, requires understanding and assessment of the value of production in various economic sectors. In addition, development of information technology plays an important role in creating jobs and production growth in countries. For instance, it has been reported that more than one-third of the US economic growth during the years 1995-1997 had been underpinned by the widespread use of the Internet and industries related to information technology (2). E-commerce is growing at an incredible speed. If this approach to business is about to be promoted in a country like Iran, the question that arises is what are the infrastructures and main components of ecommerce?

In the $21^{\text {st }}$ century, the shift from domestic marketing to global marketing in e-commerce is the primary way to communicate with customers, suppliers, and distributors. The ability to change resources and income model and update the content is very important to the success of e-commerce and as well one of the challenges to professional marketing (3).

Information technology is applied in some broad areas in sports management including how the technological revolution tools can be used in sport, the use of the Internet and web developments in education and marketing, participation in sports activities requiring low-price equipment, and reduction of the digital divide in some sports companies and organizations. Many studies have been conducted on e-commerce and its barriers. 
Aljifri, Pons, and Collins (2003), Wagner, Fillis, and Johansson (2003), Stockdale and Standing (2004), Tan, Tyler, and Manica (2007), Arivoli, Upadhyay, and Venkatesan (2011), Lawrence (2013), and Ihlström and Nilsson (2001) studied the important barriers and disincentives to the implementation of ecommerce such as lack of information security and technical and industrial infrastructures, weak education, training, and awareness about the internet, failure in understanding the needs of small and medium-sized companies, paucity of skilled personnel specializing in computer and information technology, lack of cooperation and coordination between the legal and political environment of a country with governmental laws and regulations, and cultural and social considerations (4-10). Fathian, Akhavan, and Hooraliand (2008) and Ihlström and Nilsson (2001) classified the adoption and implementation of e-business technologies into three critical factors for the success of the companies engaged in ecommerce, for all companies in a particular industry, and for single companies. Transparency, communication channels, customer pressure, supplier pressure, and governmental support are the most effective factors in successful implementation of ecommerce and effective factors in the implementation of e-commerce include company size, preparation, and transparency $(9,11)$. Abhiman and Jamborkar (2012), in a paper entitled "determinants in the implementation and operation of ecommerce", proposed a structural model and studied the effective aspects of information technology execution and compared these factors with new technology (12). Poddar (2008) presented a model in which three components of website identity, website quality, and customer tendencies are factors affecting online purchase (13).

Many studies have been carried out in the area of e-commerce in sport. Ebrahimi, Hoseini, and AmirNejad (2012) studied the barriers to the use of e-commerce in companies producing sports goods and equipment in Tehran Province and the results showed that contextual (environmental) barriers and barriers related to the nature of ecommerce are the most important ones in this sector (14). Therefore, development of ecommerce in all fields and sectors is faced with major obstacles and challenges. Despite the studies conducted on barriers to ecommerce in non-sports organizations and few studies carried out about sports organizations, there is still no general summary about the barriers to e-commerce in sport. The present study aims to identify the barriers to the entry of companies producing sports goods and equipment into the ecommerce and prioritization of these barriers. It seems necessary that all authorities, managers, researchers, and academics who are in some way engaged in the subject of ecommerce to try to identify and overcome such barriers. Thus, due to the rapid growth and changes in global and domestic markets, especially in sports equipment and goods, intense competition between companies, the importance and necessity for using IT-based business in the marketing of sports goods, lack of information sources, and existence of no field research on e-commerce in the sports industry in Iran, studying the barriers to the use of e-commerce in companies producing sports goods and equipment seems to be necessary. The results of such studies can be helpful for sports trading companies, companies producing sports equipment and goods, sports advertising companies, companies supporting the e-commerce, etc.

\section{MATERIALS AND METHODS}

This research was a field descriptivesurvey and applied study.

Participants. . Statistical population included sports general directors of youth and sports offices, presidents of active federations, and executive managers of 
Ministry of Youth and Sports. Due to limited number of population members, it was completely considered as the sample $(n=57)$. Accordingly, 31 sports general directors of youth and sports offices and 26 executive managers of Ministry of Youth and Sports filled out an author-made questionnaire for identification of barriers to e-commerce.

Tools. This questionnaire consisted of 50 items in 7 dimensions including financial barriers (items 1-8-20-22-38-39-47), technical barriers (items 2-9-10-21-26-40-4446), barriers related to readiness of companies (items 3-24-37-41-43-45-48), managerial barriers (4-11-23-29-34-36), barriers related to customer readiness (items 12-13-19-25-3132-33-35), barriers related to lack of adequate competition (6-14-27-30-42), and legal barriers (items 7-15-16-17-18-28-49-50). The resulting five-choice questionnaire was based on Likert's five-point scale. After determining the desired components and elements, preliminary questionnaire was given to 20 professionals and 10 experts of this field to elicit their comments and recommendations about the number, proportionality, and consistency of dependent and independent variables. After receiving their comments and recommendations, the questionnaire was modified, so that its content validity was confirmed. To determine the reliability, the questionnaire was distributed among 30 of the respondents and Cronbach's alpha coefficient for financial, technical, company readiness, managerial, customer readiness, lack of adequate competition, and legal dimensions was obtained $0.847,0.800,0.735,0.657,0.752$, 0.615 , and 0.825 , respectively.

Statistical Analysis. Descriptive statistics including means, standard deviations, and ranges were calculated for all measures. One sample $t$ test and factor analysis was used to examine the hypothesis of the study. Significance levels accepted at $p<0.05$. All statistical analyses were performed using
Statistical Package for Social Sciences (SPSS, Version 19.0) software.

\section{RESULTS}

Most of the respondents (47.7\%) had a bachelor's degree and then $42.1 \%$ and $8.8 \%$ of them had a master's degree and a $\mathrm{PhD}$, respectively. The mean age of respondents was 43.98 with a maximum of 55 and a minimum of 30 . Age groups 41-45 and 46-50 accounted for the highest frequency among different age groups and lowest frequency was belonged to the age group 30 and younger $(1.8 \%)$. In terms of organizational position, $22 \%, \quad 56.1 \%$, and $5.3 \%$ of respondents were senior managers, experts, and top executives, respectively. Also, all respondents were somewhat familiar with computer.

In describing the results of the questionnaire, it was observed that lack of attention to financial contexts and modern accounting infrastructures in financial dimension, low speed of internal and national networks in technical dimension, lack of attention and unfamiliarity of industry and business managers with the application of ecommerce in barriers related to readiness of companies, lack of strategic management in managerial dimension, low familiarity of consumers with benefits of e-commerce in barriers related to readiness of customers, lack of planning and efforts for application of e-commerce in different companies in lack of adequate competition, and unfamiliarity of people with legal guarantees in e-commerce (digital signature and so on) in legal dimension have the highest priorities.

According to one-sample t-test results, from the perspective of sports administrators, financial barriers have no significant impact on the application of e-commerce in companies producing sports equipment and goods. Technical barriers, company readiness, managerial barriers, consumer readiness, lack of enough adequate competition, and legal barriers were 
identified as significant barriers to the application of e-commerce in companies producing sports equipment and goods (Table 1).

Table 1: Results of one sample t-test of the effectiveness of e-commerce barriers

\begin{tabular}{cccccc}
\hline Barriers Type & $\begin{array}{c}\text { Theoretical } \\
\text { mean }\end{array}$ & $\begin{array}{c}\text { Experimental } \\
\text { mean }\end{array}$ & $\mathrm{df}$ & $\mathrm{t}$ & $\mathrm{sig}$ \\
\hline Technical & 3 & 3.47 & 56 & 5.43 & $0.001^{*}$ \\
\hline Company Readiness & 3 & 3.44 & 56 & 5.532 & $0.001^{*}$ \\
\hline Administrative & 3 & 3.55 & 56 & 7.431 & $0.001^{*}$ \\
\hline Customer Readiness & 3 & 3.58 & 56 & 8.194 & $0.001^{*}$ \\
\hline Lack of Adequate Competition & 3 & 3.54 & 56 & 7.012 & $0.001^{*}$ \\
\hline Legal & 3 & 3.67 & 56 & 8.137 & $0.001^{*}$ \\
\hline & *: Significant at $\mathrm{p}<0.01$. & & &
\end{tabular}

*: Significant at $\mathrm{p}<0.01$.

The results of factor analysis showed that sports administrators believe that customer readiness, company readiness, administrative barriers, lack of adequate competition, technical barriers, legal barriers, and financial barriers, respectively, are the priorities of barriers to the application of ecommerce in companies producing sports equipment and goods (Table 2, 3, and 4).

Table 2 - Total variance explained

\begin{tabular}{|c|c|c|c|c|c|c|}
\hline \multirow[b]{2}{*}{ Dimensions } & \multicolumn{3}{|c|}{ Eigenvalue primary } & \multicolumn{3}{|c|}{ External sum of squares bars } \\
\hline & Total & $\begin{array}{c}\text { Percentage of } \\
\text { variance }\end{array}$ & $\begin{array}{l}\text { percentage } \\
\text { cumulative }\end{array}$ & Total & $\begin{array}{c}\text { Percentage of } \\
\text { variance }\end{array}$ & $\begin{array}{l}\text { percentage } \\
\text { cumulative }\end{array}$ \\
\hline 1 & 4.698 & 67.110 & 67.110 & 4.698 & 67.110 & 67.110 \\
\hline 2 & .734 & 10.490 & 77.600 & & & \\
\hline 3 & .550 & 7.861 & 85.461 & & & \\
\hline 4 & .399 & 5.701 & 91.162 & & & \\
\hline 5 & .236 & 3.377 & 94.539 & & & \\
\hline 6 & .207 & 2.964 & 97.503 & & & \\
\hline 7 & .175 & 2.497 & 100.000 & & & \\
\hline
\end{tabular}

As observed in Table 2, based on 7 barriers to e-commerce, one factor explains $67.11 \%$ of variance of barriers to ecommerce. Thus, it can be stated that 7 components of barriers to e-commerce are common in one factor, because only the eigenvalue of the first factor is more than 1 (4.698). In other words, these 7 components altogether explain $67.11 \%$ of dimensions of barriers to e-commerce in companies producing sports equipment and goods.

Table 3. KMO and Bartlett's test for desirability factor analysis

\begin{tabular}{ccc}
\hline \multicolumn{2}{c}{ KMO (Kaiser-Meyer-Olkin) Test } & 0.87 \\
\hline \multirow{2}{*}{ Bartlett's test } & chi-square & 261.082 \\
& df & 21 \\
\cline { 2 - 3 } & sig & 0.000 \\
\hline
\end{tabular}


According to Table 3, Bartlett's test results show that the use of factors analysis is desirable and the factor derived from 7 dimensions has an acceptable validity (the observed level of significance is less than 0.05). KMO test results also show that the number of samples was suitable for factor analysis $(0.87$ is higher than the benchmark 0.50 . If the test values is greater than 0.5 , it indicates the suitability of the number of samples for factor analysis).

Table 4: Matrix components and factor Analysis barriers to e-commerce

\begin{tabular}{lc}
\hline \multicolumn{1}{c}{ Barriers Type } & Factor 1 \\
\hline customer readiness & 0.883 \\
\hline company readiness & 0.859 \\
\hline Administrative & 0.853 \\
\hline Lack of adequate competition & 0.836 \\
\hline Technical & 0.801 \\
\hline Legal & 0.796 \\
\hline Financial & 0.692 \\
\hline
\end{tabular}

According to Table 4, coefficients of factor load of each barrier to e-commerce from the perspective of sports administrators have applied to the major factor. As previously mentioned, customer readiness, company readiness, administrative barriers, lack of adequate competition, technical barriers, legal barriers, and financial barriers, respectively, are the priorities of barriers to the application of e-commerce in companies producing sports equipment and goods from the perspective of sports administrators.

\section{DISCUSSION}

The present paper aimed to study the barriers to e-commerce in companies producing sports equipment and goods from the perspective of sports administrators. The results showed that financial barriers has no significant impact on the application of ecommerce in companies producing sports equipment and goods. Although the empirical mean of financial barriers (3.14) is more than the theoretical mean (3), this difference is not significant. Stockdale and Standing (2004) studied the benefits of and barriers to the presence in e-commerce market from the perspective of small and medium businesses and found financial issues as one of the barriers to e-commerce (6). Askarian (2005), AlamdarMeybodi, Mirabi, and Mohammadgholinia (2011), Lowrence and Usman (2010), respectively, introduced economic, financial, and economic issues as the most important barrier to e-commerce (15-17). All these findings are inconsistent with the results of the present study. Difference between the types of companies studied in this paper and in other ones and differences in survey respondents can be mentioned as possible reasons for this conflict.

Study findings showed that technical barriers are significantly effective in application of e-commerce by companies producing sports equipment and goods, as the empirical mean of technical barriers (3.47) is significantly more than the theoretical mean (3). Mahdavi Adeli and HaghDoust (2008) stated that the lack of hardware, software, and telecommunication infrastructures have a considerable impact on development of e-commerce (18). Ihlström and Nilsson (2001), and Aljifri, Pons, and Collins (2003), respectively, stated that technical problems, and technical infrastructures are effective factors in development of e-commerce $(4,9)$. These 
are consistent with the results of the present study on the importance of technical barriers. From the perspective of sports administrators, barriers related to the readiness of companies producing sports equipment and goods have a significant impact on application of e-commerce.

Empirical mean of barriers related to company readiness is equal to 3.44 which is significantly more than the theoretical mean (3). Tan, Tyler, and Manica (2007) asserted that knowledge, resources, commitment, and ownership in organizational electronic readiness section and electronic readiness of government, market forces, and supportive industries in external electronic readiness part are effective factors in development of e-commerce (7). In terms of organizational factors, Hajkarimi, Azizi, and Akhavankharazian (2009), Chong (2005), Fathian, Akhavan, and Hoorali (2008), and Zhongbin, Binli, and Zhe (2010) have stated that company size, company transparency, and company readiness are effective factors in the implementation of e-commerce (11, 19-21). This is consistent with the findings of the present study.

The findings also indicated that managerial barriers are significantly effective in application of e-commerce by companies producing sports equipment and goods, as the empirical mean of managerial barriers (3.55) is significantly more than the theoretical mean (3). Abhiman and Jamborkar (2012) proposed a structural model and studied the effective aspects of information technology execution and compared these factors with new technology and the results suggested that inter-business e-commerce can improve performance and this improvement depends on the way that managers of an organization plan and implement this technology (12). Finally, it was concluded that proper change management processes can be also effective in e-commerce. Baghaei Ravari and Moghadasi (2007) came to the conclusion that managerial challenges are an obstacles to the development of e-commerce (22), which is consistent with the findings of the present study.

In addition, barriers related to customer preparation have a significant impact on the application of e-commerce by companies producing sports equipment and goods, as the empirical mean of barriers related to customer preparation (3.58) is significantly more than the theoretical mean (3). Hajkarimi, Azizi, and Akhavankharazian (2009) conducted a study in order to identify the barriers to the application of e-commerce in Iran Khodro Company and propose practical solutions for overcoming them. The results showed that lack of readiness and willingness of customers is the most important barrier to the application of ecommerce in Iran Khodro Company (20). Rahimnia et al. (2012) stated that customer trust is the main factor for the success of ecommerce (1). Poddar (2008) and presented a model in which three components of website identity, website quality, and customer tendencies are factors affecting online purchase (13). Fathian, Akhavan, and Hoorali (2008) argue that customer support is an important factor for the success of ecommerce (11). These results are consistent with the findings of the present study.

According to the results, lack of adequate competition is a significant barrier to the application of e-commerce by companies producing sports equipment and goods, as the empirical mean of lack of adequate competition (3.54) is significantly more than the theoretical mean (3). Xu, Rohatgi, Duan (2007) found that the most important factor in the acceptance of e-commerce by small and medium businesses is the pressure received from the competitors (23). Hajkarimi, Azizi, and Akhavankharazian (2009), Alamdar Meybodi and Mirabi (2011), and Fathian, Akhavan, and Hoorali (2008), respectively, stated that lack of proper competitive environment, low 
pressure from competitors, and competitive pressure are the most important factors in the development of e-commerce $(11,16,20)$.

Finally, the study findings showed that legal barriers can significantly affect the application of e-commerce by companies producing sports equipment and goods, as the empirical mean of legal barriers (3.67) is significantly more than the theoretical mean (3). Aljifri, Pons, and Collins (2003), Wagner, Fillis, and Johansson (2003), Stockdale and Standing (2004), Chong (2005), Tan, Tyler, and Manica (2007), Lowrence and Usman (2010), and Ihlström and Nilsson (2001) stated that lack of cooperation and coordination between the legal and political environment of a country with governmental laws and regulations are of the barriers to e-commerce $(4-7,9,17$, 21). This is in line with the findings of the present study.

According to the factor load obtained from factor analysis test, customer readiness, company readiness, administrative barriers, lack of adequate competition, technological barriers, legal barriers, and financial barriers with coefficients of $0.883,0.859,0.853$, $0.836,0.801,0.796$, and 0.692 , respectively, have the first to seventh ranking among the barriers to e-commerce in this sector. Hajkarimi, Azizi, and Akhavankharazian (2009) stated that lack of readiness and willingness of customers, lack of readiness and required capability of partners, behavioral and cultural barriers, technical problems, and lack of proper competitive environment, respectively, are the most important barriers to the application of ecommerce in Iran Khodro Company (20). In the present study, customer readiness was also identified as the first priority of barriers.

Finally, technical barriers rank 3 that can be minimized by development of e-banking and e-wallet, development of telecommunications infrastructures, and reducing the technical costs. Ebrahimi, Hoseini, AmirNejad (2012) concluded that contextual (environmental) factors and nature of e-commerce, respectively, are the most important barriers to the use of ecommerce in companies producing sports goods and equipment in Tehran Province (14).

\section{CONCLUSION}

According to the importance of technical dimension in the application of e-commerce in companies producing sports equipment and goods, the following items are recommended:

1- Paying the license fee for using the support and service of technology owner companies.

2- Training of manpower for the development of appropriate human resources for e-commerce.

3- Using the standard encryption algorithms and technologies based on these algorithms such as e-wallet and e-counter.

4- Constant monitoring and control of the quality of performing the duties assigned.

5- Developments in the field of telecommunication, investment in wire and wireless data transmission, and establishment of suitable communication infrastructure.

6- Increasing the Internet Bandwidth

According to the importance of company readiness dimension in the application of ecommerce in companies producing sports equipment and goods, the following items are recommended:

1- Holding seminars and workshops on necessary skill in e-commerce.

2- Investigation of the conditions necessary for successful implementation of e-commerce.

3- Recruitment of entrepreneur, innovative, and creative human resources and appointing them to different units in order to underlie the conditions. 
4- Assessment of educational needs of employees at different levels of an organization in relation to the application of e-commerce.

5- Preparing educational pamphlets for employees to be more familiar with the principles of e-commerce.

According to the importance of administrative barriers in the application of e-commerce in companies producing sports equipment and goods, the following items are recommended:

1- Strategic planning for e-commerce.

2- Senior managers' commitment to and support for e-commerce.

3- Short-term, mid-term, and long-term planning for resolving the problems.

4- Adoption of optimal laws for ecommerce.

According to the importance of customer readiness in the application of e-commerce in companies producing sports equipment and goods, the following items are recommended:

1- Offering interest-free loans and other financial facilities to citizens for computers purchase.

2- Promotion of competition in the market of companies providing Internet services in order to reduce the price of internet services.

3- Creating cultural contexts for encouraging customers to purchase electronically through the media.

4- Codification of appropriate technical and safety standards and efficient encryption techniques to ensure customer confidence in e-commerce.

5- Offering special discounts and benefits for customers who purchase electronically.

6- Establishment of a pilot program for taking orders, sales, and after sales service via the website.

According to the importance of lack of adequate competition in the application of e- commerce in companies producing sports equipment and goods, the following items are recommended:

1- Granting of subsidies and other financial facilities to companies, especially small and medium ones.

2- Elimination of multiple and conflicting laws to establish a transparent and competitive environment.

3- Providing a competitive environment for the use of e-commerce in the field of sport.

4- Offering the competitive tariffs in order to reduce the price of services.

5- Planning the necessary arrangements to allow limited presence of foreign companies and promote competition.

According to the importance of legal barriers in the application of e-commerce in companies producing sports equipment and goods, the following items are recommended:

1- Enacting stable laws and full enforcement of them to reduce risks.

2- Setting heavy penalties for violations and crimes in e-commerce.

3- Legislation and standardization of rules and regulations relating to ecommerce.

4- Proper legislation by the Parliament and proposal of proper bills in the government.

According to all mentioned above, it is hoped that managers can overcome the barriers and achieve success. The current era is rapidly changing like clouds, so management practices need to be updated. Based on the theory of natural selection, environment selects the organizations that are able to adapt themselves to changes. The present age is the era of technology and information and sports organizations are no exception. 


\section{REFFRENCES}

1. Rahimnia F, Nabizadeh T, Tarzeh Z, Amini M. Designing a conceptual model of innovation culture and mechanism's effects on developing e-commerce. Interdisciplinary Journal of Contemporary Research in Business. 2012;3(10):1033-43.

2. Amirkhani AH, Motaghi Sabet M. Scrutinizing the Obstacles of E-Insurance Development in Asia Insurance Company. Sanaat-E-Bimeh. 2010;25(1 ):157-77 [Article in Farsi].

3. Pilling D, Barrett P, Floyd M. Disabled people and the Internet: Experiences, barriers and opportunities. 2004.

4. Aljifri HA, Pons A, Collins D. Global e-commerce: a framework for understanding and overcoming the trust barrier. Information Management \& Computer Security. 2003;11(3):130-8.

5. Wagner BA, Fillis I, Johansson U. E-business and e-supply strategy in small and medium sized businesses (SMEs). Supply Chain Management: An International Journal. 2003;8(4):343-54.

6. Stockdale R, Standing C. Benefits and barriers of electronic marketplace participation: an SME perspective. Journal of Enterprise Information Management. 2004;17(4):301-11.

7. Tan J, Tyler K, Manica A. Business-to-business adoption of eCommerce in China. Information \& Management. 2007;44(3):332-51.

8. Arivoli S, Upadhyay AN, Venkatesan P. Relative Growth and Description of the nymphal instars of Tenagogonus fluviorum (Fabricius) (Hemiptera: Gerridae). Academic Journal of Entomology. 2011;4(3):72-80.

9. Ihlström C, Nilsson M. Size Does Matter - SMEs special barriers in adopting e-business. CollECTeR 2001:171-8.

10. Lawrence JE. Barriers Hindering Ecommerce Adoption: A Case Study of Kurdistan Region of Iraq. In: Zolait AHS, editor. Technology Diffusion and Adoption: Global Complexity, Global Innovation. Hershey: PA: Information Science Reference; 2013. p. 152-65.

11. Fathian M, Akhavan P, Hoorali M. E-readiness assessment of non-profit ICT SMEs in a developing country: The case of Iran. Technovation. 2008;28(9):578-90.

12. Abhiman PS, Jamborkar SS. An Analytical Study Of E-commerce Growth In Developing Country Like India. Indian Streams Research Journal. 2012;2(6):1-6.

13. Poddar R. Country Report on E-Commerce Initiatives. Ministry of Communication and Information Technology, 2008.

14. Ebrahimi S, Hoseini SE, Amir Nejad S. The Barreirs of Using Electronic Commerce in the Sport - Equipment Company Producter Province Tehran. European Journal of Sports and Exercise Science. 2012;1(4):126-9 [Article in Farsi].

15. Askarian F, Faraji Dana A, Goudarzi M, Jafari A. The Economics Survey of Sports Industry in Iran (1998 2001). Harakat. 2005;24(24):25-44 [Article in Farsi].

16. Alamdar Meybodi MM, Mirabi VR, Mohammadgholinia J. The Obstacles in Applying Electronic Commerce in Distributive Cooperatives in Tehran Province. Taavon. 2011;21(4):119-49 [Article in Farsi].

17. Lowrence JE, Usman A. Barriers to e-commerce in developing countries. Information, Society and Justice. 2010;3(1):23-35.

18. Mahdavi Adeli MH, Hagh Doust R, Shamsi. The Necessity of Electronic Trade in Iran with Attention to Its Role in Productivity of Firms in Advanced Countries. Knowledge And Development. 2008;14(21):97-120 [Article in Farsi].

19. Zhongbin Y, Binli W, Zhe L, editors. The impact on the development of sports enterprises making by the combination of E-commerce and networkmarketing. International Conference on E-Health Networking, Digital Ecosystems and Technologies (EDT); 2010 17-18 April 2010.

20. Hajkarimi AA, Azizi S, Akhavankharazian M. Designing A Model of Factors Effecting on Small and MediumSized Business E-Commerce Adoption. Knowledge And Development. 2009;16(27):51-78 [Article in Farsi].

21. Chong S, editor Determinants of Satisfaction of Electronic Commerce Implementation: Some Evidence from the Small- and Medium-Sized Enterprises. Proceedings of the Thirteenth European Conference on Information Systems; 2005; Regensburg, Germany.

22. Baghaei Ravari J, Moghadasi AR. The Implementation Challenges of a Three-Dimensional Model of Electronic Commerce in Iran. Knowledge And Development. 2007(19):83-113 [Article in Farsi].

23. Xu M, Rohatgi R, Duan Y. E-business adoption in SMEs: some preliminary findings from electronic components industry. International Journal of E-Business Research (IJEBR). 2007;3(1):74-90.

Razavi, S. G., Hosseini, S. E., Razavi, S. M. H. (2014). Ann Appl Sport Sci, 2(4): 55-66. 
تازههاى علوم كاربردى ورزش

مقاله اصيل

دوره دوم، شماره جهارم

تاريخ دريافت:

صص 99-هها، زمستان سوجسا

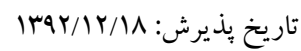

\section{موانع تجارت الكترونيك شر كتهاى توليد كننده لوازم و تجهيزات ورزشى از ديدكاه مديران ورزش كثشور}

\section{'سيد غلامرضا رضوى *، ‘سيد عماد حسينى، "سيد محمد حسين رضوى}

ا. كارشناسى ارشد مديريت ورزشى، دانشكده تربيتبدنى و علوم ورزشى، دانشگاه شمال، آمل، ايران.

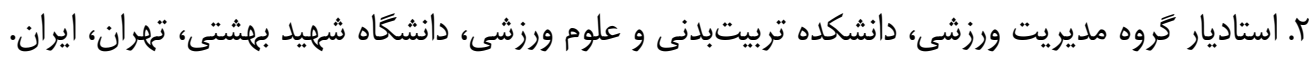

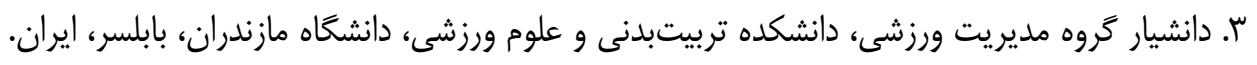

جكيده

امروزه بحث تجارت الكترونيك در صدر اولويتهاى سازمانها قرار كرفته است و سازمانهاى ورزشى نيز با بهرهگيرى از ابزارهاى اينترنت و

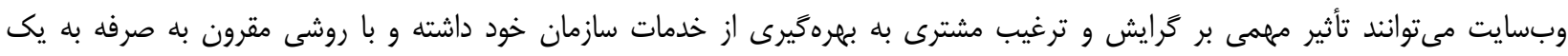

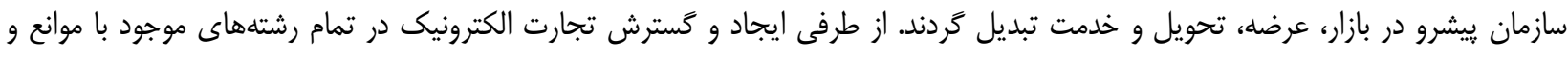

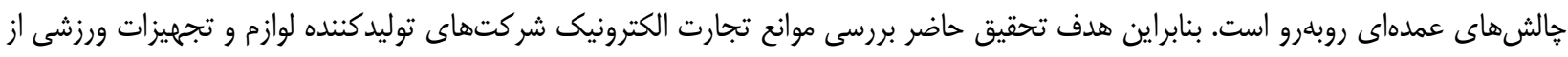

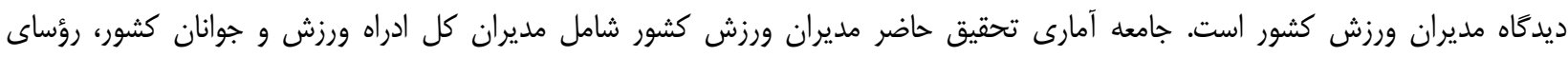

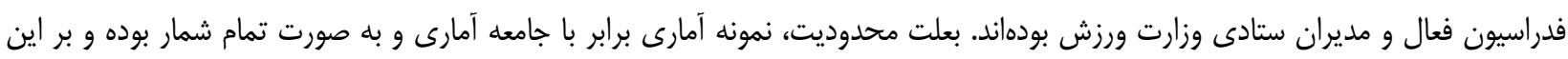

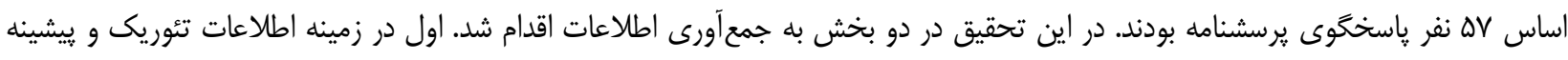

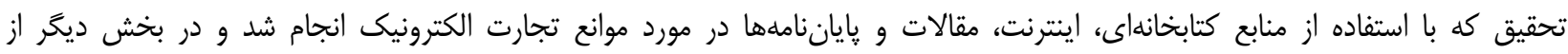

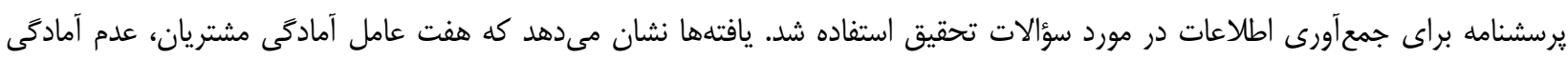

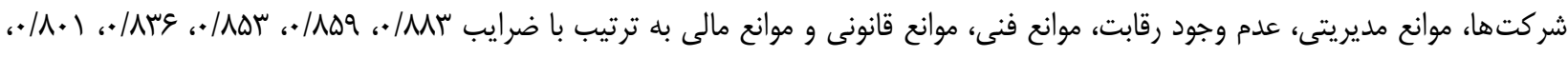

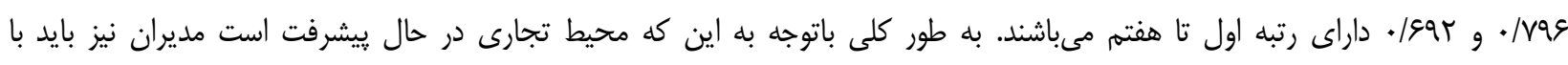

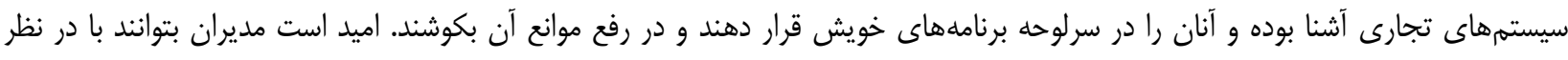

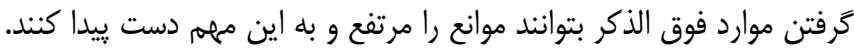
وازَّان كليدى: تجارت الكترونيك، تجهيزات ورزشى، كالاهاى ورزشى، آمادَى مشتريان، موانع.

\footnotetext{
" - نوسنده مسئول:

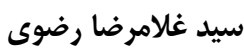
razavi.shomal@yahoo.com سيست الكترونيك غلامرضا رضوى 
